\title{
E-INTEgRATED MARKETING COMMUNiCATION OF MICRO ENTERPRISES
}

\author{
Bruno Busic, Katarina Stavlic \& Kresimir Lackovic
}
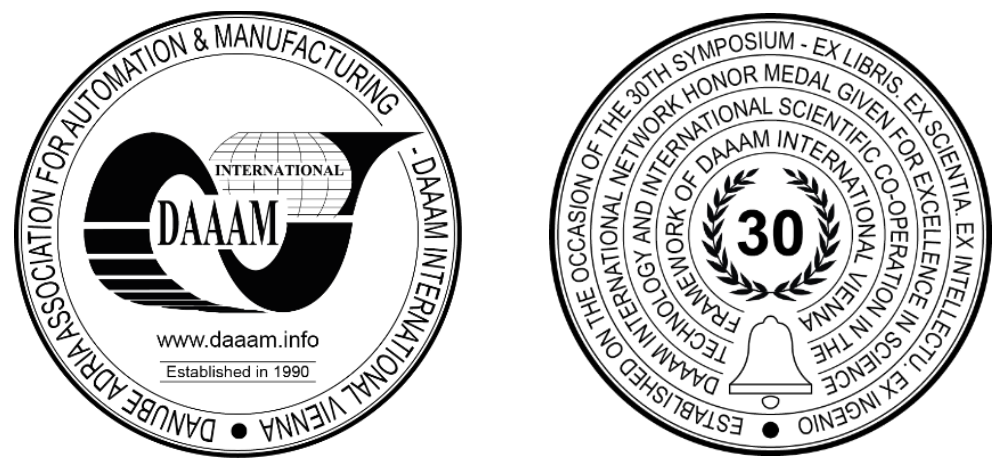

This Publication has to be referred as: Busic, B[runo]; Stavlic, K[atarina] \& Lackovic, K[resimir] (2021). E-Integrated Marketing Communication of Micro Enterprises, Proceedings of the 32nd DAAAM International Symposium, pp.04390445, B. Katalinic (Ed.), Published by DAAAM International, ISBN 978-3-902734-33-4, ISSN 1726-9679, Vienna, Austria

DOI: $10.2507 / 32$ nd.daaam.proceedings.064

\begin{abstract}
The subject of research in this paper are micro-enterprises as important factors of any national economy. The importance of small and micro-enterprises was determined, and the process of e-integrated marketing communication was defined using methods of analysis and synthesis and empirical and modelling methods. The research aims to determine the characteristics of micro-enterprises in the national economy and define the marketing process using information technologies. In micro-enterprises, the owner is the manager and thus the bearer of all creative and managerial business responsibilities, even in marketing. Accordingly, the organization of integrated marketing is defined first, and then, based on the researched possibilities of Internet technologies, integrated marketing communication as an organizational model for the efficient conduct of the process. In this way, it is possible to conduct marketing activities with minimal costs in a micro company.
\end{abstract}

Keywords: Technology; Marketing communication; Information and communication process; Micro-enterprise

\section{Introduction}

In today's globalized and very dynamic market, various forms of entrepreneurial organization are emerging. In this sense, small businesses increasingly dominated the formation of economic entities of different sizes with several employees. In such micro-enterprises, all creative and executive responsibility is borne by one person as the owner and the manager. Therefore, the research object is a micro-enterprise and the methods of analysis, synthesis, and empirical were applied to the model. The research aims first to determine the characteristics and value of small enterprises in the national economy. Then explore the possibilities provided by internet technologies and define the marketing process in online terms. It is hypothesized that Internet technologies may be an important success factor in integrated microenterprise marketing. After defining and researching the strength of micro-enterprises, a marketing strategy and integrated marketing communication were defined. Furthermore, researching the technical and technological possibilities arising from the development of information Internet technologies. This process clearly shows that marketing activities can be carried out efficiently in a micro-enterprise with minimal costs. Thus, in micro-enterprise, internal marketing activity is focused on the availability of resources, institutional support and ease of use of Internet technologies in the market [1]. Limitations on the development of integrated information and communication processes in micro-enterprises may stem from the insufficient education and preparation of new micro-entrepreneurs. That is certainly a subject for future research on this topic. 


\section{Peculiarities of micro-enterprises and entrepreneurs}

The object of this topic is an economic entity defined as a micro-enterprise. In the territory of the Republic of Croatia, this is regulated by the Accounting Act and based on the said Act [2]: Micro-entrepreneurs are those who do not exceed two of the following three conditions:

- Total assets HRK 2,600,000.00

- Income HRK 5,200,000.00

- Average number of employees during the business year - 10 employees.

In addition, the Republic of Croatia passed the Act on Encouraging the Development of Small Business with regulations according to which a micro-entrepreneur must meet the following criteria [3]:

- Number of employees less than ten employees.

- Annual income was less than 2,000,000.00 EUR.

- Assets of fixed assets less than EUR 2,000,000.00.

The data indicate the relative harmonization of the Micro Entrepreneurship Regulation Act between the Republic of Croatia and the European Union. In addition to the above data, there are research and results on other relevant indicators from which it can be concluded how much is the presence and importance of micro-enterprises in the Croatian national economy. In this sense, Figure 1 shows a survey on the number of employees in micro-enterprises in the Republic of Croatia. The graph in Figure 1 shows that, for example, in $22.60 \%$ of micro-enterprises, only one person is employed, and in $69.40 \%$, up to five persons are employed. In any case, one person is responsible for creating and executing all management decisions, usually the business owner.

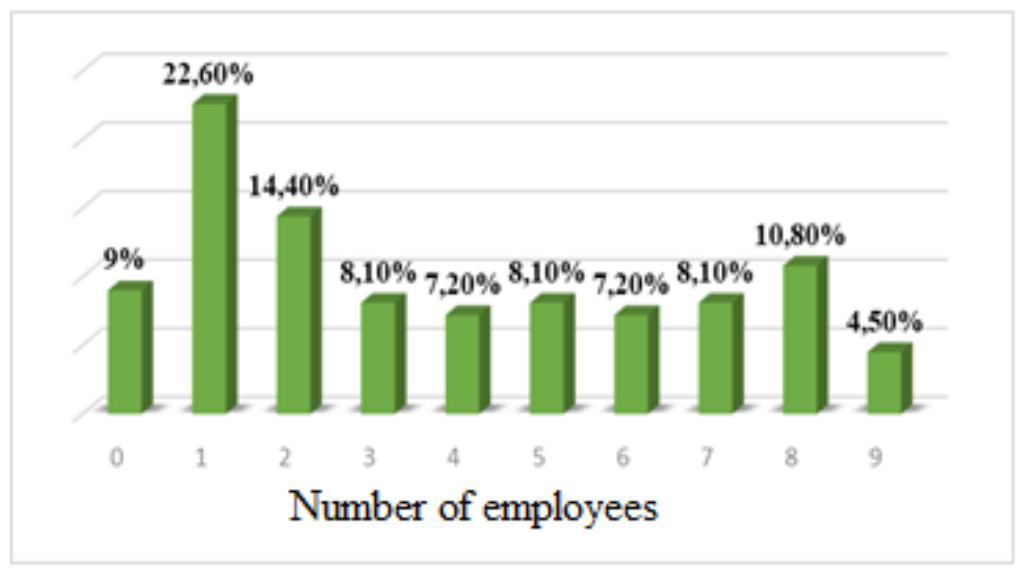

Fig. 1. Number of employees in surveyed micro-enterprises in the Republic of Croatia Source: Author's empirical research in 2017 [4]

\begin{tabular}{|c|c|c|c|c|c|}
\hline Description & In total & Micro & Small & Medium- sized & Big \\
\hline Number of entrepreneurs & 136.260 & 122.403 & 11.962 & 1.525 & 370 \\
\hline Number of entrepreneurs (part) & $100,00 \%$ & $89,84 \%$ & $8,77 \%$ & $1,11 \%$ & $0,28 \%$ \\
\hline Number of employees & 969.776 & 286.603 & 249.826 & 183.189 & 250.158 \\
\hline Number of employees (part) & $100 \%$ & $29,55 \%$ & $25,76 \%$ & $18,89 \%$ & $25,80 \%$ \\
\hline $\begin{array}{c}\text { Consolidated financial result - profit or loss for } \\
\text { the period (in HRK million) }\end{array}$ & 31.281 & -152 & 8.596 & 7.127 & 15.711 \\
\hline \begin{tabular}{c} 
Average monthly net salaries in HRK \\
\hline
\end{tabular} & 5.815 & 4.217 & 5.668 & 6.393 & 7.369 \\
\hline \multicolumn{2}{|c|}{ Index 2018=100.0 } & & 102,6 & 100,5 \\
\hline $\begin{array}{c}\text { Consolidated financial result - profit or loss for } \\
\text { the period (in HRK million) }\end{array}$ & 106,4 & 118,6 & 103 & 110,5 \\
\hline $\begin{array}{c}\text { Average monthly net salaries in HRK } \\
\text { Number of employees }\end{array}$ & 104,2 & 109,8 & 105,5 & 103,5 & 104,5 \\
\hline
\end{tabular}

Table 1. Business operations of entrepreneurs in the Republic of Croatia in 2019 by the size of the entrepreneur Source: author's calculation based on FINA data, 2020 
The social value of micro-enterprises in the Croatian economy is highlighted in the tables in Table 1, which shows the structure of the number of entrepreneurs and the number of employees in micro, small, medium and large enterprises in the Republic of Croatia in 2019. In addition to the previous exact indicators showing the value of small enterprises in the national economy, small enterprises are very successful and flexible, as can be seen from the following hypotheses [5]:

1. In many industries, small businesses can respond more quickly and at a lower cost to ever-faster changes in products and services, processes and markets.

2. A small business is attractive to gifted individuals.

To these features should be added the fact that the most significant success factor is human resources. In this sense, attention is focused on the quality and organization of employees and especially on the motivation and preparedness of the manager, who in most cases is also the owner of a micro company. The manager as an individual is in a situation to be responsible for creating, making and implementing all decisions relevant to the business. That is undoubtedly a significant advantage in terms of efficiency and the risk borne by the owner-manager. The success of a manager in a micro company and the manager's ability and motivation will depend on additional special education and the readiness to apply all new organizational and technical innovations. In any case, the manager must have a well-designed business strategy that will define the vision, elaborate goals and plan in line with the annual operational plans. This is followed by implementing and evaluating execution and analysis at the end of the strategic period as a basis for a new strategy. On this occasion, the starting point of consideration will be marketing because it is a window into the market world. Special attention is paid to marketing communication in the conditions of developed information Internet technologies. The starting position is the organization of marketing and the application of Internet technologies so that the manager can function effectively. The main goal in marketing is effective communication that includes the coordination of all marketing activities with a combination of all elements to achieve synergy effects in the creation, execution and control of marketing goals and objectives [6]. In this sense, the term integrated marketing communication has emerged.

\section{Integrated marketing communication}

In the early 1980s, there was a realization of the need for strategic integration of all marketing communication elements. The disintegration of mass markets into smaller ones, the development of new media, and the rise of consumer sophistication have resulted in a new concept in communication science known as integrated marketing communication. Until 1990, forms of marketing communication were studied and applied individually. However, changes in consumer behaviour caused by general social changes and technological advances resulted in an increasing need to integrate all communication activities and modified and fully customized communication messages. [7]. The essential facts of this term derive from its definition: "Integrated marketing communication is the process of developing and applying various forms of argumentative communication with consumers and potential customers at a given time. The goal is to influence or directly direct the behaviour of selected partners who express interest and use all acceptable forms of communication. The process starts with the potential customer and is directed backwards to develop a permanent process [8]." The ultimate goal is to build a continuous long-term communication process with customers, and this can be done efficiently with the logistical support of Internet technologies.

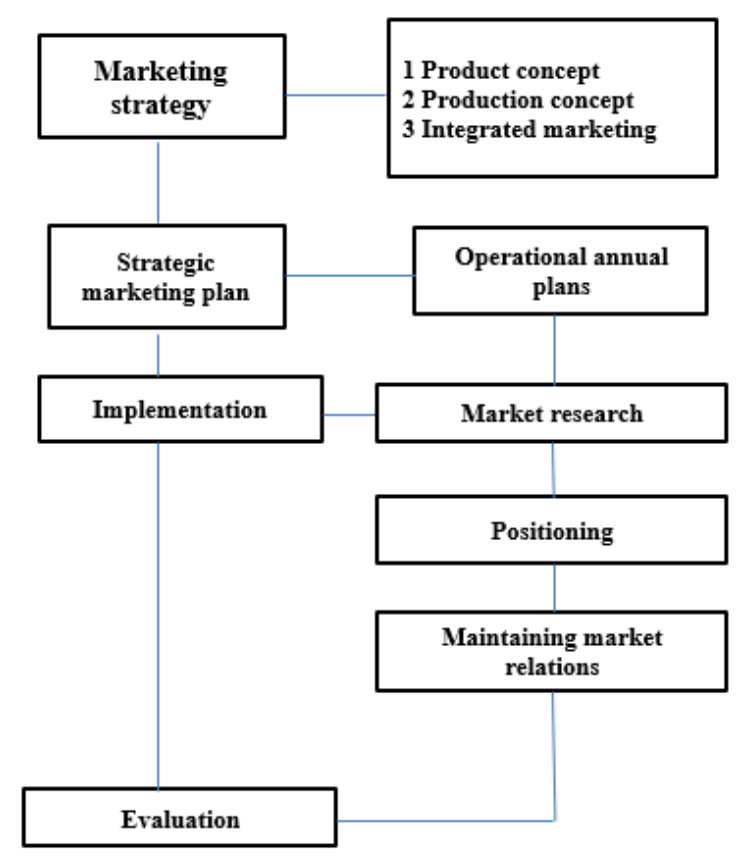

Fig. 2. The structure of the marketing process in a micro-enterprise 
Given that the micro-enterprise is complete management related to one person, it is necessary to set up such an organization of the company, especially marketing, that information technology, with the entrepreneur's readiness and motivation, be effective logistics. That means that complete marketing communication takes place at a minimal cost. In this sense, the first step is to define the marketing process.

Figure 2 presents the organizational structure of a marketing process that is appropriate for a micro-enterprise. Every micro-entrepreneur, especially when founding a company, should define a business and thus a marketing strategy. The business strategy is to determine the primary long-term goals of the company, to adjust the directions of business activities, i.e. to determine the concepts and the choice of resources needed for the realization of the set goals [9]. In this sense, everything starts from a vision that expresses the desired opportunities in the future, widely enough understood and described to adapt to specific situations [10]. After a precisely determined desire, it is elaborated in the form of goals which explain the vision in a broader form. The final design of the marketing strategy is the definition of a plan where everything should be quantified, evaluated and set deadlines for implementation. Particular attention should be paid to the very concept of the previous process. Namely, an entrepreneur can have such a product defined that already has a market due to the established qualities. Another approach is sales, in which it is necessary to organize a certain level of logistics. Given the current conditions of globalization and significant market dynamics, most micro-entrepreneurs, in particular, must immediately approach the market to maximize information and communication to establish a synergistic long-term relationship, which is integrated marketing. Therefore, its strategic conception should be positioning, and in this case, it is directing the perception of customers to the product's position concerning the competition.

According to Figure 2, after the set marketing plan, market research activities can be approached. This activity helps the company gain information about consumers and non-consumers, competition and distribution channels, which serves as a basis for identifying needs and opportunities to sell in the market, business problems, and control [11]. A prerequisite for market research is to determine the marketing mix elements for a particular micro company. That means that the product or service must be precisely defined. After that, the price system and methods of distribution of products and services are determined. The basic instrument and tool of the marketing mix with most market research activities is promotion. The first phase of research is market segmentation as dividing the market into different groups of customers who might require special products or a marketing mix. The second phase is selecting the target market as a process of assessing and selecting one or more market segments to enter. That is followed by product positioning as formulating competitive positioning and detailed marketing mix [12]. It is a plan for possible placement in the market segment. The next phase of implementation is to maintain business relationships which is the ultimate goal of the business strategy. That can be made possible by information internet technologies in a micro-enterprise. The micro-entrepreneur must certainly approach the evaluation of the implementation of the strategic plan. Evaluation should specifically identify the relationships between the plan and implementation and the causes and consequences of certain differences. In addition to these differences, the evaluation results enable a more realistic setting of the future marketing strategy and its components and instruments. In the complete strategic process, great logistical assistance is provided by information internet technologies. In addition, as one of the most significant technological phenomena of our time, the Internet provides customers with entirely new opportunities, the most important of which is to provide immediate and always open access [13].

\section{Internet logistics}

The development of information technologies at the end of the twentieth and the beginning of the twenty-first century has greatly supported entrepreneurs in the creation and implementation or integration of marketing activities. On this occasion, some internet technological possibilities have been singled out to support integrated marketing communications at a low cost.

Every micro-entrepreneur should open a web portal when founding a company because in that way, they will inform future business partners about all necessary information at no cost. The sequel follows the personalization of the web, especially in market research. Personalization aims to deliver information that is important to an individual or group of individuals among customers and suppliers in a specific form, schedule, and time intervals [14]. Opening e-mail enables direct communication with the business public appropriately and mastering Internet technologies, especially after market segmentation, should open a blog, Twitter and Instagram. The blog's role is that it is actually an online diary, the author of which almost every day publishes various current comments and news, which describe the events about the company's business with photos and links. It should be emphasized that these are thematic blogs of particular interest to customers and suppliers, and the rest of the public [15]. For a shorter form of communication, especially when defining the market segment, Twitter or microblogging service is used, based on exchanging short messages and socializing or following other users [16]. After positioning a company or product, the entrepreneur can address customers directly. This type of discussion is known as a forum which is the technological evolution of bulletin boards. From a technological point of view, forums or boards are web applications that manage user-generated content [17]. Entrepreneur's education in the positioning phase enables synchronous communication through video conferencing, which is organized by agreement from time to time with well-known customers from the market environment. Videoconferencing is the connection of individuals and groups through telecommunications networks and video technology so that people have the impression of simultaneously attending meetings in the form of a live video link on a computer screen [18]. 
That completely establishes the connection of entrepreneurs with target customers from the market segment, so the maintenance of business relationships follows. One very high-quality internet approach enables Customer-RelationshipManagement (CRM). It is an approach to e-business based on understanding customer behaviour through meaningful communication and all to attract and retain customers, develop their loyalty, and increase the company's profitability [19]. The primary goal of CRM is to build a long-term and profitable relationship with a selected market segment [20].

The basic components of CRM are building and managing customer relationships through marketing, observing interpersonal relationships by stages, then managing those relationships at each stage, and controlling the distribution of information. When establishing CRM through marketing, companies can use a variety of tools to help with organizational design. It should be noted in particular that interactions in multiple customer relationships can be linked to transactions. All this leads to cost reductions and thus higher profitability. Therefore, CRM enables the interaction of companies with a large number of Internet channels, portals, and platforms and thus achieves a very strong connection with current and former customers and makes it easier to establish new connections.

After completing the implementation of the marketing strategy and as part of the integrated marketing communication, the maintenance of customer relations can be completed through social networks with a special warning on Facebook and Linkedin. The concept of Facebook was designed to connect people who already know each other in real life via the Internet. The main feature of Facebook is numerous applications because, for example, it is possible to have virtual pets, receive virtual gifts and greeting cards, solve quizzes and play video games. Facebook offers the ability to control privacy, so users can hide their profile and photos and protect themselves from unknown visitors [21]. Linkedin is a businessoriented social networking service mainly used for professional networking, especially in recruitment and sales [22]. All of the above social networks provide an opportunity to personalize each other's information after discussions at video conferences. In this way, the entrepreneur creates even closer relationships with customers and suppliers and with the rest of the public. Such integrated marketing communication processes achieve a long-term connection with minimal costs and loss of time.

\section{Integrated internet marketing information and communication process}

Regardless of the company's size, every micro-entrepreneur should organize the necessary information and communication marketing process that will, with the help of Internet technologies, integrate the entire business and thus marketing activities. In this sense, Figure 4 shows a systematic information and communication process in which all marketing activities are fully integrated following the set strategy. The picture shows that the framework marketing plan can be distributed through a personalized web portal and e-mail, which goes to already recognized customers. Market research by collecting data using blogs and Twitter reduces the number of customers, and the forum already determines the market segment. After a video meeting with selected customers from the segment, fascinating customers are selected as the target group. After that, the market capacity of the segment is assessed, and the position or part of the market capacity is determined. Evaluating and maintaining customer relationships is most effective through CRM. Increasing the quality of relationships can take place through social networks. With the proposed process, a micro-entrepreneur can perform all market research activities, i.e. the implementation of a marketing plan, alone with minimal costs.

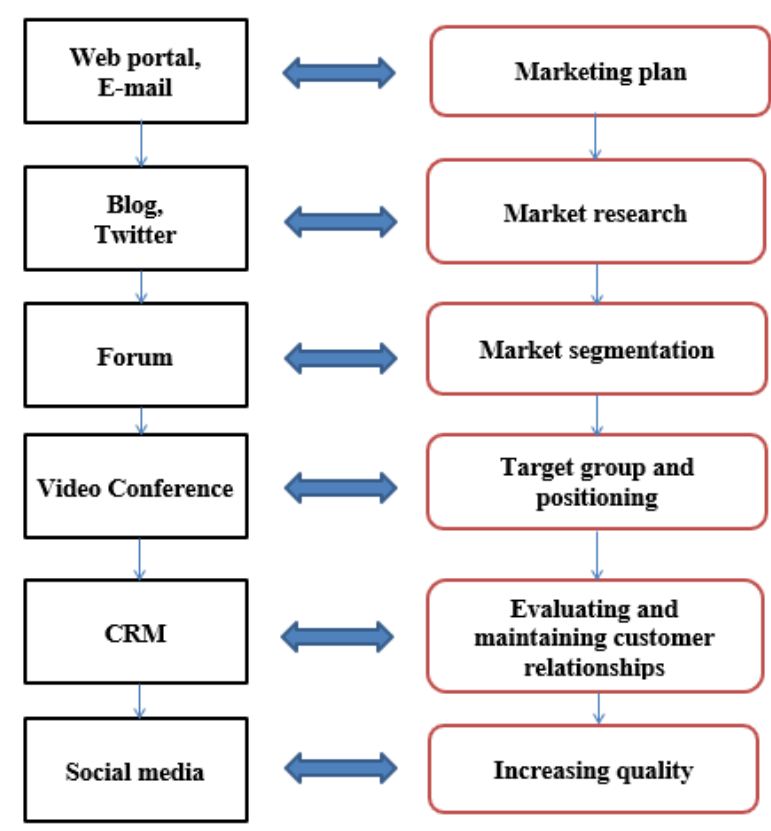

Fig. 3. Integrated information and communication process of marketing activities in a micro-enterprise 
Figure 3 shows that the manager of a micro-enterprise can perform all marketing activities alone using applications and other capabilities provided by Internet information technologies. Each phase of marketing activities supports the appropriate portal or platform, and the complete marketing process takes place with minimal participation of managers. Therefore, it is clear from the course of activities and IT support that this is a very effective way of managing marketing in a micro-enterprise. The proposed model and the obtained results indicate the presence of continuous investment in new technologies and IT in micro-enterprises, which is evident from previous research [23], especially the presence of modern technologies in the business of micro-enterprises through investments in the acquisition of new technologies, application of IT and computer skills. The proposed model can be implemented in micro enterprises, provided that the entrepreneur or manager has a basic knowledge of information and marketing technologies, and that they understand the importance of the impact of the application of this model on their business. By applying this model, it is possible to improve existing marketing and communication processes, and positively influence the improvement of business. Disadvantages and possible negative outputs can be seen through the lack of interest of entrepreneurs in such activities and impatience in anticipation of visible results of the application of this model. Possible limitations of this research are visible in the lack of feedback from micro-entrepreneurs on the proposal of this model.

\section{Conclusion}

Based on the previous considerations, more can be concluded. First of all, micro-enterprises are a crucial factor in the national economy. That is why they deserve research to increase the efficiency of all business functions, especially marketing. In most cases, the owner is also responsible for all creative and executive decisions, even in marketing. One of the basic problems faced by entrepreneurs / owners is insufficiently developed marketing communication due to lack of their time and professional knowledge. In this sense, an integrated information and communication process is set up as an organizational form that allows the owner to communicate effectively with customers. Based on the research of the possibilities of Internet technologies, integrated marketing communication was defined as an instrument for the effective conduct of all marketing activities adapted to the micro-enterprise. That allows the micro-enterprise manager to perform all creative and management activities at a minimal cost, and the observed marketing communication problems with the market were solved. The development of this process can enable the education of entrepreneurs in business and especially IT. That is a potential area for further study of this topic, with an emphasis on exploring the impact of new or improved e-marketing communication on the business performance of micro-enterprises.

\section{References}

[1] Kurian, S.; Ramanathan, H. \& Andrlic, B. (2019). The Role Internal Marketing in The Promotion of Technology Usage Among Teachers: An Empirical Investigation of the Mediating Role of Extrinsic Factors Leading to Improved Technology Use, Proceedings of the 30th DAAAM International Symposium, pp.0030-0037, B. Katalinic (Ed.), Published by DAAAM International, ISBN 978-3-902734-22-8, ISSN 1726-9679, Vienna, Austria. DOI: 10.2507/30th.daaam.proceedings.004

[2] Accounting law, National newspapers, Narodne novine no. 78/15,134/15,120/16, 116/18, 42/20, 47/20, Art. 5, Available from: https://www.zakon.hr/z/118/Zakon-o-ra\%C4\%8Dunovodstvu, Accessed on: 2021-06-15

[3] Small Business Development Encouragement Act (2016). National newspapers, Narodne novine no. 29/02, 63/07, 53/12, 56/13, 121/16, Art. 3, Available from: https: //www.zakon.hr/z/527/Zakon-o-poticanju-razvojamaloggospodarstva, Accessed on: 2021-06-15

[4] Štavlić, K. (2018). Micro entrepreneurship - resources, potentials and success, Veleučilište u Požegi, pp. 64. ISBN 978-953-7744-32-8., Požega

[5] Siropolis, N. C. (1995). Menadžment malog poduzeća, prijevod, Mate, ISBN 953-6070-14-6, Zagreb

[6] Kesić, T. (2003). Integrirana marketinška komunikacija, Opinio, pp. 28. ISBN 953-98250-0-8, Zagreb

[7] Shimp, T. A. (2000). 'Advertising Promotion Supplemental Aspects of Integrated Marketing Communications (fifth edition). The Dryden Press: pp. 22-23.

[8] Schultz, D. E. (1993). Integrated Marketing Communication: Maybe definition is in the Point of View, Marketing News, January 18, 1963., pp 17

[9] Chandler, A. D. (1962) Strategy and Structure, pp 16, The MIT Presse, Cambridge

[10] Duličić, Ž. \& Škaro, G. (2001). Redefiniranje vizije i misije hrvatskih brodarskih poduzeća, Ekonomska misao i praksa, Vol 10, no 2, pp 161. ISSN 1330-1039

[11] Marušić, M. \& Vranešević, T. (2001). Istraživanje tržišta, ADECO, pp.6. ISBN 953-97228-3-7, Zagreb

[12] Kotler, P. (1988). Upravljanje marketingom 1, prijevod, Informator, pp. 258. ISBN 86-301-0142-3, Zagreb

[13] Marinović, M. \& Andrlić, B. (2012). Social Geolocation in Tourism - Interrelationship of Web 2.0 and Geography. Proceedings of the 23rd International DAAAM Symposium, Volume 23, Br.1, pp. 0337, ISSN 2304-1382, ISBN 978-3-901509-91-9

[14] Kim, W. (2002). Personalization: Definition, Status and Challenges ahead, Journal of Object Technology , No.1, Available from: Http://www.jot.fm/issue_2002_05/colimn3/ Accessed on: 2021-04-21

[15] https://blog.dnevnik.hr/plazma/2006/05/1621035764/definicija-i-podjela blogova.html?page=blog\&id=1621035764\&subpage=0\&subdomain=plazma, Accessed on: 2021-04-21 
[16] Ružić, D.; Biloš, A. \& Turkalj, D. (2009). e-Marketing, Faculty of Economics, pp. 26. CIP 120902038, Osijek

[17] "Bulletin Community Forum - FAQ: What is a bulletin board?". Available from: https://forum.vbulletin.com/articles, Accessed on: 2021-06-14

[18] Leksikografski zavod Miroslav Krleža, Available from: https://proleksis.lzmk.hr/50177/, Accessed on: 2021-0810

[19] Panian, Ž. (2003). Odnosi s klijentima (U e-poslovanju), Sinergija, ISBN 953-6895-11-0, Zagreb

[20] Andrlić, B.; Šostar, M. \& Banožić, M. (2020). Application of E-Processes in Tourism Marketing, Proceedings of the 31st DAAAM International Symposium, pp.0004-0008, B. Katalinic (Ed.), Published by DAAAM International, ISBN 978-3-902734-29-7, ISSN 1726-9679, Vienna, Austria DOI: 10.2507/31st.daaam.proceedings.001

[21] Grbavac, J. \& Grbavac, V. (2014). Pojava društvenih mreža kao globalnog komunikacijskog fenomena, Media, culture and public relations, No. 5, pp. 212. ISSN 1333-8371 (Print), ISSN 1848-8374 (Online)

[22] Nicholas Lemann, N. (2015). "Reid Hoffman's Big Dreams for LinkedIn - The New Yorker". The New Yorker

[23] Stavlic, K. (2020). Comparative Analysis of the Presence of the New and Modern Technologies in Micro Enterprises, Proceedings of the 31st DAAAM International Symposium, pp.0936-0942, B. Katalinic (Ed.), Published by DAAAM International, ISBN 978-3-902734-29-7, ISSN 1726-9679, Vienna, Austria DOI: 10.2507/31st.daaam.proceedings. 130 